ISSN: 2581-8341

Volume 04 Issue 03 March 2021

DOI: 10.47191/ijcsrr/V4-i3-10, Impact Factor: 5.825

IJCSRR @ 2021

www.ijjcsrr.org

\title{
Studies on Fish feed Formulation of Indian Major Carps from Aquatic Macrophytes, Lemna minor and Eichhornia crassipes
}

\author{
Sipraswarupa Sahoo ${ }^{1}$, Hemanta Kumar Sahu ${ }^{2}$ \\ 1,2PG Department of Zoology, Block-6, Research Lab 3, Maharaja Sriram Chandra Bhanja Deo University, Takatpue, Baripada, \\ Mayurbhanj, odisha-757003
}

\begin{abstract}
In the present study, highest SGR (Specific Growth Rate) was obtained in 20\% in Lemna minor and $10 \%$ in Echhornia crassipes. The leaves of aquatic plants had considerable amount of crude protein and crude lipid, which improves the growth of fingerlings of fish upto a certain levels of inclusions, thereby reducing the feed cost. The slow growth performance might be due to absence of natural feed in the laboratory culture. The leaf meals inclusion has much advantage in growth performance of fish. However these leaf meals need processing to lower their fibre content, which to be used as fish feed.
\end{abstract}

KEYWORDS: Fish Feed, Lemna Minor, Eichhornia Crassipes, Cost Effective, Aquatic Macrophytes

\section{INTRODUCTION}

Artificial feed plays an important role in semi intensive fish culture, where it is required to maintain a high density of fish than the natural fertility of water can support (Jhingran, 1991). Feed is undoubtedly the single largest operating cost in intensive fish culture especially using cat fish, which needs high protein (Otubusin et al. 2007). Proteins are major organic material in fish tissue constituting 65\%-75\% of dry weight (De Silva, 1989). Lipids constitute 6.28\% of fish diet. Lipids for fish are important source of energy and help in transportation of fat soluble vitamins and steroids. Essential fatty acids promote normal larval development, fish growth and reproduction (Mishra and Mukhopadhaya, 1996). Fish feed generally constitute $60 \%-70 \%$ of operational cost in intensive and semi intensive aquaculture systems (Singh et al., 2006). To increase protein retention from the diet, the quality and mixture of different proteins and the inclusion of partly pre-digested proteins have shown good results (Calheires, 2003, FAO, 2004, Lunger et al., 2007).

\section{MATERIALS AND METHODS}

Feed Ingredients: Fish meal, ground nut oil cake, rice bran, soybean meal were collected from local market. The two aquatic weeds used in the feed, Lemna minor and Eichhornia crassipes were collected from local water bodies.

Feed Additives: Sunflower oil, Cod liver oil and Vitamin mineral premix. Cod liver oil and vitamin were collected from local medicine store. For vitamin mineral premix Ambiplex, Brihans lab, Pune and Argimin, Glaxo India Ltd., Mumbai was used. Sunflower oil was collected from local grocery store.

Equipments Used: Mixer grinder, Sieve, Balance, Pelletizer

Preparation Method: The feed ingredients other than leaf meal were collected from local market and sundried. They were grounded thoroughly and passed through fine meshed sieve to ensure homogeneity. Lemna minor and Eichhornia crassipes plants were collected from local water bodies. Leaves were collected in case of Eichhornia and sundried. Dried leaves were grounded thoroughly and sieved to obtain fine powder. Powdered ingredients were subjected to proximate analysis following procedures of AOAC (2000).

\section{Proximate Analysis}

Moisture: Weighed amount of sample (W1) was placed in the oven for 12 hours at $105^{\circ} \mathrm{C}$. The dried sample again kept in oven until constant weight (W2) was obtained. The loss weight was recorded. 


\section{International Journal of Current Science Research and Review}

ISSN: 2581-8341

Volume 04 Issue 03 March 2021

DOI: 10.47191/ijcsrr/V4-i3-10, Impact Factor: 5.825

IJCSRR@ 2021

www.ijjcsrr.org

$$
\text { Moisture }(\%)=\frac{\mathrm{W} 2-\mathrm{W} 1}{\mathrm{~W} 1}
$$

Ash: Total Ash $(\%)$ was determined by burning $2 \mathrm{gm}$ of dried sample which then placed in a muffle furnace for ignition at $550-600^{\circ} \mathrm{C}$ till the residue was obtained. Which then cool and weight.

$$
\operatorname{Ash}(\%)=\frac{\text { Wt. Of Ash } \times 100}{\text { Wt. Of Sample }}
$$

Organic matter $(\%)=100(\%)-$ Ash $(\%)$

Crude Protein: Crude protein was estimated using micro Kjeldhal method.

Crude Protein $(\%)=\mathrm{N} 2(\%) \times 6.25$, whereby;

$$
(\mathrm{N})(\%)=\frac{\text { Volume of H2SO4 used } \times \text { Normality of H2SO4 } \times 0.014 \times 250 \times 100}{\text { Weight of Sample } \times 10}
$$

Where $0.014=$ Standard volume of $0.1 \mathrm{~N} \mathrm{H} 2 \mathrm{SO} 4$ used to neutralise $1 \mathrm{ml}$ of Ammonia

$250=$ Dilution of digested mixture

$100=$ for $\%$ of $\mathrm{N} 2$

$10=$ Volume of the digested and diluted sample used

6.25 = Assumed factor for equation of $\mathrm{N} \%$ to crude lipid

Crude Lipid: Crude lipid content was determined using soxhlet apparatus.

$$
\text { Crude Lipid }(\%)=\frac{\text { Weight of crude lipid }}{\text { Weight of Sample }} \times 100
$$

\section{RESULTS AND DISCUSSION}

Proximate analysis of feed ingredients such as fish meal, soybean meal, GNOC, leaf meals were made (Table- 1$)$. Crude protein (\% $\mathrm{CP}$ ) of fishmeal was 63.02, ground nut oil cake was 42.5 and soybean meal was 35.3 and rice bran 12.3. The leaves of two aquatic macrophytes contains 20.3\%, crude protein (Lemna minor) and 13.5\% (Echheronia crassipes) respectively. Crude lipid (CL \%) content of the fishmeal was $11.3 \%$, followed by rice bran and GNOC which were $10 \%$ each and soybean contained $20 \%$ CL. The two leaves used had CL content of $4.3 \%$ and $2.6 \%$ in Lemna and Eichhornia respectively. Ash content was highest in fishmeal (22.75\%) followed by Eichhornia leafmeal (21.7\%) and was lowest in Lemna minor(13.5\%). Ricebran had $8.5 \%$ ash and soybean had $5 \%$ ash.

Table 1. Proximate Analysis (\% of dry matter) of ingredients used for fish feed formulation

\begin{tabular}{lllll}
\hline Ingredients & Moisture & CP & CL & Ash \\
\hline Ricebran & 7.6 & 12.1 & 10.0 & 8.5 \\
GNOC & 8.4 & 42.5 & 10.3 & 10.6 \\
Soybean meal & 9.1 & 35.4 & 2.1 & 5.1 \\
$\begin{array}{l}\text { Fish meal } \\
\text { Lemna minor leaf } \\
\text { meal }\end{array}$ & 13.73 & 63.4 & 11.2 & 22.73 \\
$\begin{array}{l}\text { Eichhorniacrassipes } \\
\text { leaf meal }\end{array}$ & 1.05 & 20.4 & 4.1 & 13.5 \\
\hline
\end{tabular}

However, proximate composition of feed 1 containing Lemna minor leafmeal was presented in table-2. Proximate analysis of feed 1 containing E. Crassipes leafmeal was presented in table-3. The crude protein(\%) of control feed containing fishmeal but no leaf 


\section{International Journal of Current Science Research and Review}

ISSN: 2581-8341

Volume 04 Issue 03 March 2021

DOI: 10.47191/ijesrr/V4-i3-10, Impact Factor: 5.825

IJCSRR@ 2021

wWw.ijcsrr.org

meal was slightly higher (37.3\%) and $\mathrm{T}_{1}, \mathrm{~T}_{2}$ and $\mathrm{T}_{3}$ have $\mathrm{CP}$ level $35.6 \%, 34.1 \%$ and $33.6 \%$ respectively.The crude lipid (\%) of control feed was $8.3 \%$ and $\mathrm{T}_{1}, \mathrm{~T}_{2}$ and $\mathrm{T}_{3}$ had $6.7 \%, 6.85 \%$ and $5.6 \%$ respectively. The ash (\%) of control feed was highest i.e., $13.6 \%$ followed by $\mathrm{T}_{1}, \mathrm{~T}_{2}$ and $\mathrm{T}_{3}, 11.3 \%, 11 \%$ and $10.7 \%$ respectively. Moisture $\%$ of control feed was found to be $2.4 \%, \mathrm{~T}_{1}, 1.3 \%$ $\mathrm{T}_{2}$ and $1.7 \% \mathrm{~T}_{3}$ respectively.

Table 2: Proximate Composition (\% of dry matter) of Feed 1 containing Lemna minor leaf meal

\begin{tabular}{llccc}
\hline Ingredients & \multicolumn{4}{l}{ Inclusion level of Lemna leaf meal } \\
& $\mathbf{0 \%}$ & $\mathbf{1 0 \%}$ & $\mathbf{2 0 \%}$ & $\mathbf{3 0 \%}$ \\
& Control & $\mathbf{T 1}$ & $\mathbf{T 2}$ & $\mathbf{T 3}$ \\
\hline Lemna minor leaf meal & 0 & 3.6 & 7.0 & 10.5 \\
Fish meal & 19.9 & 16.4 & 12.8 & 10.4 \\
GNOC & 39.1 & 39.0 & 39.2 & 39.3 \\
Rice Bran & 39.0 & 39.0 & 39 & 38.8 \\
Sunflower Oil & 1.0 & 1.0 & 1.0 & 1.0 \\
Vitamin and Mineral premix & 1.0 & 1.0 & 1.0 & 1.0 \\
& 100 & 100 & 100 & 100 \\
\hline
\end{tabular}

Table 3: Proximate analysis of Feed 1

\begin{tabular}{llllll}
\hline $\begin{array}{l}\text { Experimental } \\
\text { Feed 1 }\end{array}$ & $\begin{array}{l}\text { Crude } \\
\text { Protein \% }\end{array}$ & Crude Lipid \% & Ash \% & Moisture \% & OM \% \\
\hline Control & 37.3 & 8.0 & 13.6 & 2.4 & 84.51 \\
T1 & 35.6 & 6.7 & 11.6 & 1.3 & 85.44 \\
T2 & 34.1 & 6.7 & 11.1 & 1.3 & 85.51 \\
T3 & 33.6 & 5.6 & 10.7 & 1.7 & 85.16 \\
\hline
\end{tabular}

Accordingly the proximal composition and proximal analysis of feed-2 containing Echhornia leafmeal were presented in table-4 and table-5 respectively. The crude protein (\%) of control feed was $36.73 \%$, which was slightly higher due to higher percentage of fishmeal. Other three feeds $\mathrm{D}_{1}, \mathrm{D}_{2}$ and $\mathrm{D}_{3}$ had $35.43 \%, 35.23 \%$ and $35.14 \%$ of crude protein. The crude lipids (\%) of the four feeds were $5.07 \%, 4.7 \%, 4.6 \%$ and $4.39 \%$ in controls $\mathrm{D}_{1}, \mathrm{D}_{2}$ and $\mathrm{D}_{3}$ respectively. The ash was highest in $\mathrm{D}_{3}(5.33 \%)$ followed by $\mathrm{D}_{2}(4 \%)$ and $\mathrm{D}_{1}(3.1 \%)$. Ash (\%) was lowest in control feed (2.1\%). Moisture (\%) of $\mathrm{D}_{1}$ was highest $(8.1 \%)$ followed by $8.1 \%$ in $\mathrm{D}_{2}, 8.2 \%$ in $\mathrm{D}_{3}$ and $7 \%$ in control.

Table 4: Proximate Composition (\% of dry weight) of Feed 2 containing Eichhornia crassipes leaf meal

\begin{tabular}{lllll}
\hline Ingredients & \multicolumn{4}{l}{ Inclusion level of Lemna leaf meal } \\
& $\mathbf{0 \%}$ & $\mathbf{1 0 \%}$ & $\mathbf{2 0 \%}$ & $\mathbf{3 0 \%}$ \\
& Control & $\mathbf{D}_{\mathbf{1}}$ & $\mathbf{D}_{\mathbf{2}}$ & $\mathbf{D}_{\mathbf{3}}$ \\
\hline Eichhornia crassipes leaf meal & 0 & 10 & 20 & 30 \\
Fish meal & 20.0 & 15 & 13 & 8 \\
GNOC & 20.0 & 21 & 19 & 21 \\
Soybean meal & 27.9 & 26 & 23 & 19 \\
Rice Bran & 30.1 & 26 & 23 & 20.0 \\
Cod liver oil & 1.0 & 1.0 & 1.0 & 1.0 \\
Vitamin Mineral Premix & 1.0 & 1.0 & 1.0 & 1.0 \\
& 100 & 100 & 100 & 100 \\
\hline
\end{tabular}




\section{International Journal of Current Science Research and Review}

ISSN: 2581-8341

Volume 04 Issue 03 March 2021

DOI: 10.47191/ijcsrr/V4-i3-10, Impact Factor: 5.825

IJCSRR@ 2021

www.ijcsrr.org

Table 5: Proximate analysis of Feed 2

\begin{tabular}{llllll}
\hline $\begin{array}{l}\text { Experimental } \\
\text { Feed 2 }\end{array}$ & $\begin{array}{l}\text { Crude } \\
\text { Protein \% }\end{array}$ & Crude Lipid \% & Ash \% & Moisture\% & DM \% \\
\hline Control & 36.76 & 5.08 & 2.1 & 7.0 & 94 \\
D1 & 35.44 & 4.86 & 3.0 & 8.3 & 91.8 \\
D2 & 35.26 & 4.56 & 4.0 & 8.1 & 91.84 \\
D3 & 35.14 & 4.37 & 5.33 & 8.0 & 92.0 \\
\hline
\end{tabular}

Most conventional ingredients used in fish feed are fishmeal, soybean meal, groundnut oil cake etc which in developing countries are scarce and costly to farmers (Fasakinet al., 1999) causing hardship of gaining due profit from aquaculture. Fishmeal is often used in aqua feeds as they are essential source of amino acids, vitamins and minerals and they generally enhance palatability (Davies and Arnold, 2000). However, nearly all researchers agree that an alternative ingredient should be used in aqua feed industry in place of fishmeal, whose supplies are limited although demand for it is expected to rise (Yilmaz et al., 2005).

Considerable attention has been devoted to replacement of fishmeal with plant protein sources such as soybean meal (Oliva Teleset al., 1994), groundnut oilcake (Davies and Ezenwa, 2010), muccuna seed meal (Sidduraju and Becker, 2001), winged bean (Fagbenero, 1999) and various legumes (Hossain et al., 2001).

Now day's serious efforts are made towards use of non conventional feed sources as ingredients in fishfeed (Ali et al., 2006). Utilization of aquatic macrophytes commonly occurring in freshwater bodies can serve two benefits at a time. 1 . These may be used as alternative ingredients for making farm based aquafeeds, and 2 . Their use as ingredients in making fishfeed can reduce their wastage and minimise cost of fishfeed production along with supply of sufficient nourishment to fish without affecting the ambient environment (Mandal et al., 2010). With high abundance as well as excessive proliferation, aquatic macrophytes are easily available in fresh water ecosystem (Mandal et al., 2010). However their utilization as fishfeed component is not much remarkable despite their unique nutrient status (Mandal et al., 2010). Lemna minor is found to be the most promising one, $40 \%$ of which is blended with commercial feed has exhibited significant performance (Elsafai, 2004) advocated inclusion of 20-40\% duckweed in fish diet on dry weight basis as it had better digestibility Coefficient than any other commercial plant material used. Stetlikova and Adamek (2004) opined that Elodea Canadensis as having higher concentration of phosphorus, potassium and ash than that of Myriophyllum spicatum, Potamogeton pectinatus and Spirodella polyrrhiza and reasonably the most preferred plant to Nile tilapia than others. Tender leaves of Myriophyllum spicatum were more preferable to tilapia because young leaves contained higher concentration of protein and mineral than does older leaves (Begon et al., 1997).Bairagiet al., 2002 reported successful utilization of Lemna leafmeal as a dietary ingredient in the diet of Labeo rohita fingerlings upto 30\% inclusion. Robinsion et al., 2001 found that inclusion of Lemna minor meal into channel catfish diets had no effects on the rate of feed conversion.

\section{CONCLUSION}

It is concluded that inclusion of Lemna meal into commercial diets would not significiantly affect feed quality and that duckweed meal may be a suitable protein source for practicial diets of channel catfish. The use of leafmeal as a possible fishmeal substitute is receiving increasing attention by fish nutritionists throughout world to 5 reduce feed cost (Bairagi et al., 2004). It is however important that the selectedplant sources do not conflict with the interests of human food security or their domestic animals (Amisah et al., 2009). Inclusion of such aquatic macrophytes as food and feed may serve dual purpose, i.e., bringing more plant derived foodstuff for aquaculture and making aquaculture more cost effective for farmers. Therefore, a combined effort comprising plant taxonomists, nutritionists, physiologists and fish culturists is warranted for making use of untapped potential of these macrophytes as feed for fish.

\section{ACKNOWLEDGEMENT}

The authors are grateful to the Head of Zoology, Maharaja Sriram Chandra Bhanja Deo University, Baripada for providing laboratory facilities and Head Zoology Rajsunakhala college, Nayagarh (Odisha) for allowing the laboratory to set up the experiment. 


\section{International Journal of Current Science Research and Review}

ISSN: 2581-8341

Volume 04 Issue 03 March 2021

DOI: 10.47191/ijcsrr/V4-i3-10, Impact Factor: 5.825

IJCSRR@ 2021

www.ijcsrr.org

\section{REFERENCES}

1. Abdelghany, E. A. and Ahmad, M. H. 2002. Effects of feeding rates on growth and production of Nile tilapia, Common Carp and Silver carp poltculture in fertilized ponds, Aquacult. Res. (33): 415- 423.

2. Swapon, M. R. S., yeasmin, T. U., Rahman, M. S. and Ali, M. S. 2003. Replacement of Sesame peel cake by Duckweed (Lemna minor) in broiler diet. Pakistan Journal of Biological Science. 6 (16): 1450-1453.

3. Ali, A., Bhatti, M. N., Khan, N. and Rehman, M. H., 2006. Role of soil and water chemistry in aquaculture. Proceedings of International Conference on "Solving problems of fresh water farming in Pakistan" November 27-28, 2006 UVAS pp $139-141$.

4. Amisah, S., Oteng, M. A. and Ofori, J. K. 2009. Growth performance of African cat fish Clarias gariepinus, feed varying inclusion levels of Leucaena leucocephala leaf meal. Journal of Applied science and Environmental Management 13(1) 21-26.

5. AOAC (2000) Association of Official Analytical Chemists, Official methods of Analysis, $17^{\text {th }}$ ed., Washington DC, USA.

6. APHA. 2005, American Public Health Association Standard Methods for the Examination of Water and Wastewater. $21^{\text {st }}$ edition, Washington D.C.

7. Bairagi, A., Sarkar Ghosh, K. S. and Ray, A. K. 2004. Evaluation of the nutritive value of Lucaena leucocephala leafmeal inoculated with fish intestinal bacteria Bacillus subtilis and Bacillus circulans in formulated diets for rohu, Labeo rohita fingerlings. Aquaculture Research (35)436-446.

8. Begon, M., Harper, J. L. and Townsend, C. R. 1997.Ekologie: jedinci, populace a spolecenstva (Ecology: indivisuals,populations and communities) I. Vyd.Vydavatelstvi University Palackeho, Olomouc. P.107.

9. Calheiros, D. 2003. Alternate sources of protein in feed for cultural fish. A case study on Atlantic cod fry Gadusmorhua. Final project 2003, UNU, Fishery Training programme.

10. Das, K. M., Mohanty, S. N. and Sarkar, S. 1991. Optimum dietary protein to energy ratio for Labeorohita fingerlings. In proceedings of the $4^{\text {th }}$ Asian Fisheries Society, Spec. Publ., 5: 2005.

11. Davis, D. A. and Arnold, C. R. 2000. Replacement of fishmeal in practical diets for pacific white shrimp Litopenaeu svannamei. Aquaculture (185) 291-298.

12. De Silva, S. S. and Anderson, T. A. 1995. Fish Nutrition in Aquaculture, Chapman and Hall, London, pp 319.

13. De Silva, S. S. 1989. Digestibility estimates of natural and artificial diets, in fish nutrition Research in Asia (Eds.). Asian Fisheries Society, Manila, PP 36-45.

14. Ducan, D. B. 1955, Multiple range and multiple F-tests Biometrics, 11:1-42.

15. EI-Safai, S. A., EI-Gohany, A. F., Verreth, A. L. J., Schrama, W. J. and Gijen, H. 2004. Apparent digestibility coefficient of duckweed Lemna minor fresh and dry for Nile Tilapia, Oreochromis niloticus. Aquacult. Res.(35) 574-586.

16. FAO. 2004. State of World Fish Nutrition in practice. INRA, Parsis 459-468. Fisheries and Aquaculture 2004. FAO, Rome, Italy.

17. Faskin, E. A., Balogun, A. M. and Fagbanro, O. A. 2001. Evaluation of sun dried water fern Azolla Africana and duckweed, Spirodella polyrrhiza, in pratical diets for Nile Tilapia, Orechromis niloticus fingerlings. Journal of applied Aquaculture. II (4): 83-92.

18. Fasakin, E. A., Balogun, A. M. and Fasure, B. E. 1999. Use of duckweed, Spirodellapolyrrhiza as a protein feed stuff in practical diets for tilapia, Oreochromisniloticus. Aquaculture Research (305) 313-318.

19. Guna, Sandhya Rani and Patra, A. K. 2007. Evalution of Nutritional Impact of water weed-based feeds on the growth rate of Labeorohita . M.Phil.Thesis, Utkal University, Bhubaneswar.

20. Hossain, M. A., Focken, U. and Becker, K. 2001. Evaluation of an unconventional legume seed Sesbania aculeate as a dietary protein source for common carp, Cyprinuscarpio, L. Aquaculture (198) 129-140.

21. Jackson, A. J., Capper, B. S. and Matty, A. J. 1982. Evaluation of some plant proteins in compound diets for the Tilapia. Sarotherodonmossambicus, Aquaculture. 27: 97-109.

22. Jhingran, V. G. 1991. Fish and Fisheries of India. $3^{\text {rd }}$ Ed., Hindustan Publishing Co., Delhi, India.

23. Liang, J. K. and Lovel, R. T. 1971. Nutritional value of water hyacinth in channel cat fish feeds. Hyacinth Control Journal, 9 (1): $40-4$. 


\section{International Journal of Current Science Research and Review}

ISSN: 2581-8341

Volume 04 Issue 03 March 2021

DOI: 10.47191/ijcsrr/V4-i3-10, Impact Factor: 5.825

IJCSRR@ 2021

www.ijjcsrr.org

24. Lunger, A. N., McLean, E., Craig, S. R. 2007. The effects of organic protein supplementation upon growth, feed conversion and texture quality parameters in juvenile cobia (Rachcentrroncanadum) Aquaculture 264: 342-352.

25. Mandal, R. N., Datta, A. K., Sarangi, N. and Mukhopadhya, P. K. 2010. Diversity of aquatic macrophysics as food and feed components to herbivorous fish- a review. Indian journal Fish, 57(3) 65-73.

26. Mishra,S. and Mukhopadhyay, P. K. 1996. Effects of some formulated diets on growth, feed utilization and essential amino acid deposition in Clariasbatrachus fry, Indian J. Fish 43 (4) 333- 339.

27. Mohapatra, S. B. and Patra, A. K. 2013a. Effect of partial replacement of fishmeal with duckweed (Lemna minor) feed on the growth performance of Cyprinuscarpio fry. IOSR- Journal of Agriculture and Veterinary Science. 4 (2): $34-37$.

28. Oliva-Teles, A., Gouveia, A. J., Gomes, E. and Rema, P. 1994. The effect of different processing treatments on soybean meal utilization by rainbow trout, Oncorynchusmykiss. Aquaculture (124) 343-349.

29. Otubusin, S. O., Osofero, S. A., Olafe, O. O. and Agbebi, O. T. 2007. High yields and growth of catfish (Clariasgariepinus) in floating bamboo net cages system trials in south western Nigeria. Europian Journal of Scientific Research 16(2) 238244.

30. Panda, Swati, Patra, A. K. and Mohanty, S. K. 2012. Asian journal of Water, Environment and Pollution. 9(3): 83-89.

31. Patra, A. K. 2015b. Evalution of the duckweed (Lemna minor) meal as partial replacement for fish meal on the growth performance of Labeorohita ( Ham.) fry. European Journal of Experimental Biology. 5(10): 18-23.

32. Pattnaik, Nandini, and Patra, A. K. 2012. Partial replacement of fish meal with Lemna minor leaf meal on the growth performance of Clariasbatrachus. Proceeding of International Conference on Environmental Governance and Green Technology. PP-28-30.

33. Robinson, E. H. and Li, M. H. and Manning, B. B. 2001. A practical guide to nutrition, feeds and feeding of catfish (second edition). Mississippi Agricultural and Forestry Experiment Station Bulletin No.1113. Mississippi State University, USA.

34. Stetlikova, I. and Adamek, J. 2004. Feeding selectivity and growth of Nile Tilapia (Oreochromisniloticus) fed on temperate zone of aquatic macrophytes. Czek J. Animal Science (49) 271-278.

35. Yilmaz, E., Sahin, A., Duru, M. and Akyurt, I. 2005. The effect of varying dietary energy on growth and feeding behaviour of common carp Cyprinuscarpio.

Cite this Article: Sipraswarupa Sahoo, Hemanta Kumar Sahu (2021). Studies on Fish feed Formulation of Indian Major Carps from Aquatic Macrophytes, Lemna minor and Eichhornia crassipes. International Journal of Current Science Research and Review, 4(3), 224-229 